\title{
PENINGKATAN BERAT BADAN BALITA GIZI KURANG DENGAN PEMBERIAN MAKANAN NUTRISI TINGGI BERBAHAN BAKU TEMPE DAN KEMBANG KOL DI WILAYAH KERJA PUSKESMAS KABERE
}

\author{
Salma $^{1}$, Haniarti ${ }^{2}$, Nurhaeda ${ }^{3}$ \\ 1,2,3 Program Studi Kesehatan Masyarakat, Fakultas Ilmu Kesehatan Masyarakat, \\ Universitas Muhammadiyah Parepare \\ Email: salmapuetrydurey@gmail.com
}

\begin{abstract}
ABSTRAK
Permasalahan gizi di Indonesia semakin kompleks seiring terjadinya transisi epidemiologi. Menurut laporan kegiatan penimbangan posyandu di Puskesmas Kabere pada tahun 2020 terdapat sebanyak 28 balita gizi kurang. Tujuan penelitian ini adalah untuk mengetahui peningkatan berat badan balita gizi kurang dengan pemberian makanan nutrisi tinggi berbahan baku tempe dan kembang kol di wilayah kerja Puskesmas Kabere Kabupaten Enrekang. Jenis penelitian ini adalah metode kuantitatif dengan analisis quasi eksperimen design dengan rancangan non equivalent control group. Populasinya adalah balita gizi kurang yang ada di wilayah kerja Puskesmas Kabere. Sampel penelitian ini adalah balita yang mengalami gizi kurang 14 balita yang diberikan perlakuan dan 14 balita yang tidak diberikan perlakuan balita gizi kurang yang berada di wilayah kerja puskesmas Kabere dengan menghitung zcore. Analisis data dilakukan dengan menggunakan uji independen sample t-test dengan bantuan program SPSS versi 20. Lokasi penelitian ini dilakukan di wilayah kerja Puskesmas Kabere. Adapun waktu penelitian dilakukan pada bulan Juli-Agustus 2020. Hasil penelitian menunjukkan bahwa pemberian makanan nutrisi tinggi berbahan baku tempe dan kembang kol dapat meningkatkan berat badan secara signifikan terhadap balita gizi kurang. Sehingga disarankan orang tua balita memberikan asupan gizi yang cukup untuk balita gizi kurang agar status gizinya dapat terus membaik.
\end{abstract}

Kata kunci: Peningkatan BB, Gizi Kurang, Tempe, Kembang Kol. 


\title{
INCREASING WEIGHT FOR CHILDREN WITH LESS NUTRITION BY PROVIDING HIGH NUTRITIONAL FOOD IN RAW MATERIALS TEMPE AND COLUMBAGE IN WORKING AREA PUBLIC HEALTH CENTER KABERE
}

\begin{abstract}
Nutritional problems in Indonesia are getting more complex as the epidemiology transition occurs. According to reports of posyandu weighing activities at Kabere Puskesmas in 2020 there were 28 malnourished toddlers. The purpose of this study was to determine the increase in body weight of malnourished toddlers by providing high nutritional food made from tempeh and cauliflower in the working area of Kabere Public Health Center, Enrekang Regency. This type of research is a quantitative method with a quasi-experimental design with a non-equivalent control group design. The population is malnutrition under five in the working area of Puskesmas Kabere, The samples of this research were children under five who were malnourished, 14 under five who were given treatment and 14 children who were not given treatment for under-nutrition who were in the working area of the Kabere Community Health Center by calculating zcore, Data analysis was performed using the independent sample t-test with the help of the SPSS version 20 program. The location of this research was conducted in the working area of the Kabere Community Health Center. The research was conducted in July-August 2020.The results showed that the provision of high nutritional food made from tempeh and cauliflower could significantly increase body weight in malnourished children under five. So it is recommended that parents of toddlers provide adequate nutritional intake for under-nutrition children so that their nutritional status can continue to improve.
\end{abstract}

Keywords: weight gain,Tempe,Cauliflower

\section{PENDAHULUAN}

Asupan gizi berhubungan erat dengan kecerdasan dan kesehatan anak, jika pola asuh dan pemberian makanan dari ibu tidak terpenuhi untuk anak maka anak akan kekurangan gizi dan dapat mengganggu pertumbuhan dan dapat menyebabkan terjadinya gizi kurang, gizi buruk bahkan anak tumbuh pendek dan tidak sama dengan anak seusiannya (Ruswindil, 2009).

Timbulnya masalah kekurangan dan kelebihan gizi disebabkan oleh pola makan yang kurang baik. Gizi kurang 
merumpakan salah satu penyakit akibat gizi yang masih merupakan masalah di Indonesia. Masalah gizi pada balita dapat berdapak terhadap kualitas sumber daya manusia, sehingga jika tidak diatasi dapat menyebabkan lost generation. Kekurangan gizi dapat mengakibatkan gagal tumbuh kembang, meningkatkan angka kematian dan kesakitan serta penyakit terutama pada kelompok usia rawan gizi yaitu Balita. Kurang gizi atau gizi buruk merupakan penyebab kematian 3,5 juta anak di bawah usia lima tahun (balita) di dunia (Lilis Fauziah, 2017).

Balita yang sehat, cerdas dengan bergizi yang seimbang adalah dambaan semua orang tua. Gangguan gizi pada balita dapat menyebabkan gangguan tumbuh kembang anak, misalnya

stunting, wasting dan gangguan perkembangan mental . Banyak faktor yang mengakibatkan terjadinya kasus gizi kurang. Ada dua faktor terjadinya masalah gizi, faktor langsung yaitu kurangnya asupan gizi dari makanan,

akibat terjadinya penyakit yang mengakibatkan infeksi dan faktor tidak langsung yaitu ketersediaan pangan tingkat rumah tangga, perilaku dan budaya dalam pengolahan pangan dan pengasuh anak, pengelolahan lingkungan yang buruk dan pelayanan kesehatan yang tidak memadai (Ainun Mardhiah, 2020).

Tempe tergolong ekonomis dan dapat diterima semua lapisan masyarakat serta tempe bermanfaat mencegah terjadinya masalah gizi, baik kekurangan gizi maupun kelebihan gizi . Tempe juga mengandung vitamin dan mineral penting seperti asam folat, vitamin B12, zat besi, tembaga, dan Seng . Kandungan energi dalam 100 gram tempe sebesar 199,1 Kalori dan kandungan protein dalam 100 gram tempe masing-masing 19 gram. Keunggulan gizi tempe lainnya adalah kandungan asam amino yang sangat tinggi, sampai 85 kali kedelai (Arsinah Habibah Fitriah, 2017)

Kubis bunga atau sering juga disebut sebagai kembang kol (Brassica oleracea var.botritys L.) merupakan sayuran yang baik untuk dikonsumsi dikarenakan memiliki banyak manfaat bagi kesehatan dan memiliki kandungan gizi yang cukup lengkap (Novriani, 2016)

Kembang kol berperanan penting untuk kesehatan manusia, karena mengandung vitamin dan mineral yang dibutuhkan oleh tubuh. Manfaat nutrisi kembang Kol bagi kesehatan adalah mampu mengurangi risiko stroke, mengandung beberapa jenis phytochemical yang membantu mengurangi risiko kanker, mengandung vitamin $\mathrm{C}$ dan selenium membantu memperkuat sistem kekebalan tubuh, menjaga tingkat kolesterol tubuh, mengurangi racun dalam darah dan hati, kandungan thiocyanate dan glucosinolate membantu meningkatkan kemampuan hati untuk menetralisir zat berbahaya (Amazin, 2015).

Secara nasional, prevalensi gizi buruk dan kurang pada anak balita sebesar 19,6\%, Sedangkan sasaran Sustainable Development Goals (SDGs) 
tahun 2019 yaitu 17\%. Oleh karena itu, prevalensi gizi buruk dan kurang secara nasional harus diturunkan sebesar $2,6 \%$ dalam periode 2015 sampai 2019 (Profil Kesehatan Indonesia, 2013).

Umumnya pada peringkat menengah dibandingkan propinsi lainnya di Indonesia menurut data status gizi balita hasil pravelansi gizi buruk dan kurang di Sulawesi Selalatan, yakni Jeneponto (36\%), Takalar (34\%), Bantaeng (33\%), Pinrang (32\%), Gowa (31\%) dan Pangkep (30\%). Sementara pravelansi stunting di Sulawesi Selatan, yakni Enrekang (45,8\%), Sinjai (43,7 \%), Tana Toraja $(43,0 \%)$, Toraja Utara $(42,4$ $\%)$, Pangkep (41,9 \%), Maros (41,2 \%), dan Bone (40,1\%)(Kemenkes RI, 2018).

Data jumlah balita gizi kurang di Kabupaten Enrekang pada tahun 2019 yaitu 180 balita gizi kurang, sedangkan jumlah balita gizi kurang di Puskesmas Kabere hingga juli tahun 2020 terdapat 28 gizi kurang (Puskesmas Kabere, 2020)

Cara mengatasi balita dengan gizi kurang salah satunya adalah dengan cara memenuhi konsumsi makanan setiap hari untuk memenuhi kecukupan nutrisinya, Orang tua balita harus mengurangi jajanan dengan aroma gurih dan manis, karena hal tersebut dapat memberi rasa kenyang sehingga asupan gizi tidak terpenuhi, upaya untuk meningkatkan berat badan balita adalah dengan pemberian PMT yang mengandung tinggi protein dan tinggi kalori sesuai dengan berat badan balita sehingga dapat memenuhi kebutuhan gizinya (Sukini, 2017)
Protein tempe tergolong mudah dicerna sehingga protein dapat digunakan untuk menambah berat badan terutama pada balita.Tempe yang dibuat dari kacang kedelai telah dimanfaatkan sebagai sumber protein nabati. Komposisi tempe kedelai menunjukkan defisit pasangan asam amino metionin-sistin, secara menyeluruh mengandung unsur zat gizi yang cukup tinggi: $25 \%$ protein (17 gram protein/100gram), $5 \%$ lemak, $4 \%$ karbohidrat dan $60 \%$ air, sumber vitamin B12 yang cukup tinggi, rendah lemak, bebas kolesterol (Sukini ,2017)

Kembang kol merupakan sayuran yang dikonsumsi pada bagian krop bunga (curd). Setiap 100 gram curd kembang kol mengandung 245 kalori, 88 air, 4 protein , 0,3 lemak , 6 karbohidrat, 1,5 serat, 150 kalsium, 325 kalium, 800 karotin, 100 vitamin C (Rovianti, 2019)

Berdasarkan uraian di atas, maka peneliti ingin melihat bagaimana peningkatan berat badan pada balita gizi kurang dengan Pemberian makanan nutrisi tinggi berbahan baku tempe dan kembang kol di wilayah kerja Puskesmas Kabere

\section{BAHAN DAN METODE}

Metode penelitian yang digunakan dalam penelitian yaitu metode kuantitatif dengan menggunakan analisis quasi eksperimen design yang bersifat non equivalent control group, penelitian dilakukan di wilayah kerja Puskesmas Kabere Kecamatan Cendana Kabupaten Enrekang. 
Waktu penelitian ini dilakukan selama 1 bulan pada balita gizi kurang.Populasi dalam penelitian ini adalah ini adalah seluruh balita yang mengalami gizi kurang di wilayah kerja Puskesmas kabere sebanyak 28 balita.Sampel penelitian ini adalah balita yang mengalami gizi kurang 14 balita yang di berikan perlakuan dan 14 balita yang tidak diberikan perlakuan balita gizi kurang yang berada di wilayah kerja puskesmas Kabere dengan menghitung zscore.

Instrumen yang digunakan dalam penelitian ini adalah timbangan berat badan dan kuesioner.Untuk mendapatkan hasil peningkatan berat badan peneliti menggunakan timbangan berat badan, yaitu alat mekanik untuk mengukur berat badan balita yang telah di kalibrasikan terlebih dahulu.peningkatan berat badan responden pada kelompok eksperimen diukur sebelum dan sesudah diberikan makanan nutrisi tinggi, kemudian hasilnya dicatat pada lembar hasil pengukuran.

\section{HASIL}

Faktor penyebab langsung dipengaruhi oleh makanan anak dan penyakit infeksi, sedangkan faktor penyebab tidak langsung dipengaruhi oleh ketahanan pangan dalam keluarga, pola asuh anak, pelayanan kesehatan, kesehatan lingkungan, tingkat pengetahuan orang tua, tingkat pendapatan, jenis pekerjaan, tingkat pengetahuan, jumlah anggota keluarga dan social budaya.Untuk itu dalam menurunkan jumlah balita gizi kurang dapat diatasi dengan pemenuhan gizi melalui pemberian makanan nutrisi tinggi.

Makanan nutrisi tinggi berbahan baku tempe dan kembang kol diberikan kepada balita gizi kurang selama 1 bulan, diberikan tiga kali dalam seminggu pada siang hari. Sebelum melakukan penelitian terlebih dahulu melakukan penimbangan berat badan pada balita gizi kurang pada kelompok eksperimen dan kelompok kontrol, kemudian untuk kelompok eksperimen dilakukan pemberian makanan nutrisi tinggi berbahan baku tempe dan kembang kol sedangkan kelompok kontrol tidak diberikan kemudian di lakukan penimbang berat

badan kembali untuk melihat perkembangan dan perbandingan berat badan pada kelompok eksperimen dan kelompok kontrol.

Hasil penelitian yang di peroleh dengan menggunakan timbangan berat badan dan berupa formulir pengkajian sampel yang di sesuaikan dengan tujuan khusus peneliti yang akan dicapai. Setelah data terkumpul dilakukakan pemeriksaan ternyata semuanya memenuhi syarat untuk di ikutkan dalam pengelolaan dan analisis data, Kemudian di beri kode sesuai kelompok-

kelompoknya, untuk menganalisis menggunakan uji independen sample ttest dan diolah dengan menggunakan program SPSS. 
JURNAL SURYA MUDA, 3(1), 2021

p-ISSN 2656-5811

e-ISSN 2656-825x

Tabel 1 Distribusi responden berdasarkan karakteristikbalita gizi kurang di wilayah kerja Puskesmas Kabere

\begin{tabular}{|c|c|c|}
\hline Karakteristik balita & Frekuensi (f) & Persen (\%) \\
\hline \multicolumn{3}{|l|}{ Jenis kelamin } \\
\hline Laki-laki & 13 & 46.4 \\
\hline Perempuan & 15 & 53.6 \\
\hline \multicolumn{3}{|c|}{ Kelompok umur (bulan) } \\
\hline $12-23$ & 5 & 17.9 \\
\hline $24-35$ & 7 & 25.0 \\
\hline $36-47$ & 11 & 39.5 \\
\hline $48-60$ & 5 & 17.9 \\
\hline Jumlah & 28 & 100.0 \\
\hline
\end{tabular}

Sumber : Data primer 2020

Berdasarkan tabel diatas atau 53,6\%. Pada golongan umur 36-47 menunjukkan bahwa proporsi 28 bulan yaitu sebanyak 11 balita dengan responden yang terpilih, balita dengan besaran 39,5\% sedangkan presentase jenis kelamin laki-laki sebanyak 13 balita yang paling sedikit yaitu $17,9 \%$ terdapat atau 46,4\% dan balita dengan jenis 10 balita. kelamin perempuan sebanyak 15 balita

Tabel 2 Perbedaan karakteristik Antara Kelompok Eksperimen Dengan Kelompok Kontrol Kelompok

Eksperimen Kontrol

Jenis kelamin (\%)

\begin{tabular}{lccc} 
Laki-laki & $46,2 \%$ & $53,8 \%$ & 0,705 \\
perempuan & $53,3 \%$ & $46,7 \%$ & \\
\hline Umur (Mean) & 32,00 & 38,86 & 0,029 \\
\hline
\end{tabular}


Sumber : Data primer 2020

Tabel 2 menunjukkan bahwa jenis kelamin kelompok eksperimen balita dengan jenis kelamin laki-laki yaitu 46,2\% dan balita dengan jenis kelamin perempuan yaitu $53,3 \%$ sedangkan pada kelompok kontrol balita dengan jenis kelamin laki-laki yaitu 53,8\% dan balita dengan jenis kelamin perempuan yaitu $46,7 \%$ dengan nilai $p$ value 0,705 artinya tidak ada perbedaan jenis kelamin antara kelompok eksperimen dengan kelompok kontrol.

Umur kelompok eksperimen memiliki nilai rata-rata yaitu 32,00 sedangkan pada kelompok kontrol memiliki nilai rata-rata yaitu 38,86 . Nilai $p$ value pada kelompok eksperimen dan kelompok kontrol yaitu 0,029 artinya, bahwa ada perbedaan umur antara kelompok eksperimen dengan kelompok kontrol.

Table 3 Perbedaan Berat Badan Balita Sesudah dan Sesudah Pemberian Makanan NutrisiTinggi Berbahan Baku Tempe dan KembangKol Di Wilyah Kerja Puskesmas Kabere

\begin{tabular}{|c|c|c|}
\hline Eksperimen & Kontrol & \\
\hline \multirow[t]{2}{*}{ Mean $(\min -\max ) \pm$ sd } & Mean (min- & $P$ \\
\hline & $\max ) s d$ & $\Delta$ \\
\hline \multicolumn{3}{|l|}{ Sebelum } \\
\hline $9,0414(7,00-11,05)$ & $9,8136(5,03-13,00)$ & 0,023 \\
\hline 1,35 & 2,59 & 0,1207 \\
\hline \multicolumn{3}{|l|}{ Sesudah } \\
\hline $9,1621(7,00-11,25)$ & $9,8793(5,15-13,00)$ & 0,030 \\
\hline 1,40 & 2,57 & 0,0657 \\
\hline
\end{tabular}

Tabel 3 menunjukkan bahwa berat badan kelompok eksperimen sebelum pemberian makanan nutrisi tinggi berbahan baku tempe dan kembang kol memiliki nilai rata-rata yaitu 9,0414 sedangkan pada kelompok kontrol memiliki nilai rata-rata yaitu 9,8136 . Dengan nilai $p$ value yaitu 0,023 . Itu berarti ada perbedaan berat badan antara 
kelompok eksperimen dengan kelompok kontrol.

\section{Pada kelompok eksperimen} sesudah pemberian makanan nutrisi tinggi berbahan baku tempe dan kembang kol dengan jumlah sampel 14 balita memiliki nilai rata-rata yaitu 9.1621dan nilai minimum 7,00 dan maximum 11,25 dengan nilai sd 1,40. Sedangkan pada kelompok kontrol dengan sampel 14 orang memiliki nilai rata-rata 9,8793dan nilai minimum 5,15, maximum 13,00. Dengan nilaip value yaitu 0,030 , artinya bahwa ada perbedaan berat badan antara kelompok eksperimen dengan kelompok kontrol, menggunakan uji statistik independent sampel t test.

Perubahan berat badan balita selama satu bulan pada kelompok eksperimen tampak terjadi peningkatan berat badan rata-rata sebesar 0,1207 berat badan. Sedangkan pada kelompok kontrol terjadi perubahan berat badan ratarata.0,0657 berat badan. Hal ini menunjukan bahwa kelompok kontol juga mengalami kenaikkan berat badan tetapi tidak sesignifikan kelompok eksperimen, di mana kelompok eksperimen mencapai kenaikkan 0,1207 berat badan.

\section{PEMBAHASAN}

Kembang kol merupakan salah satu jenis makanan untuk perkembangan otak anak. Kembang kol kaya akan Vitamin C dan Vitamin $\mathrm{K}$ yang merupakan vitamin otak untuk anak yang baik untuk mendukung perkembangan otak si kecil. Kembang kol merupakan sayuran yang dikonsumsi pada bagian krop bunga (curd). Setiap 100 gram curd kembang kol mengandung 245 kalori, 88 air, 4 diserap sekalipun oleh anak yang menderita gizi buruk. Jumlah asam amino bebas pada tempe meningkat 1-85 kali dari kedelai. Ketersediaan nitrogen pada tempe juga meningkat dari 6,5 pada kacang kedelai menjadi 39 pada tempe. Tempe mempunyai kandungan protein, 0,3 lemak, 6 karbohidrat, 1,5 serat, 150 kalsium, 325 kalium, 800 karotin, 100 vitamin C (Rovianti, 2019)

Protein tempe tergolong mudah dicerna sehingga protein dapat digunakan untuk menambah berat badan terutama pada balita. Tempe yang dibuat dari kacang kedelai telah dimanfaatkan sebagai sumber protein nabati. Komposisi tempe kedelai menunjukkan defisit pasangan asam amino metionin-sistin, secara menyeluruh mengandung unsur zat gizi yang cukup tinggi: $25 \%$ protein (17 gram protein/100gram), $5 \%$ lemak, $4 \%$ karbohidrat dan $60 \%$ air, sumber vitamin B12 yang cukup tinggi, rendah lemak, bebas kolesterol (Sukini ,2017)

Hasil penelitian menunjukkan bahwa berat badan balita kelompok eksperimen sebelum pemberian makanan nutrisi tinggi berbahan baku tempe dan kembang kol dengan angka mean 9.0414 dan sesudah pemberian makanan nutrisi tinggi berbahan baku tempe dan kembang kol capai angka mean 9.1621 dalam 1 bulan ada kenaikan mencapai 0,1207 berat badan. Sedangkan balita yang dijadikan kelompok kontrol dengan 
angka mean 9,8136 dalam 1 bulan penelitian mencapai 9,8793 ada kenaikan yaitu 0,0657berat badan. Hal ini menunjukan bahwa kelompok kontol juga mengalami kenaikan berat badan tetapi tidak sesignifikan kelompok eksperimen, dimana kelompok eksperimen mencapai kenaikan 0,1207 berat badan.

Hasil penelitian disesuaikan dengan penelitian (Sukini, 2017) yang menunjukkan ada pengaruh pemberian tahu-tempe terhadap peningkatan berat badan balita karena tahu dan tempe merupakan makanan tradisional Indonesia yang mengandung protein nabati. protein dapat digunakan untuk menyediakan energi, tapi karena peranan protein yang esensial dalam pertumbuhan, pemeliharaan, dan perbaikan, maka kalori yang cukup harus disediakan dalam diet dari sumber non protein. Protein dihemat sebagai sumber energi ketika ada karbohidrat yang cukup dalam diet untuk memenuhi kebutuhan energi tubuh.

\section{KESIMPULAN}

Berdasarkan penelitian yang telah dilakukan dapat disimpulkan sebagai berikut:

1. Balita yang di jadikan kelompok eksperimen sebelum pemberian makanan nutrisi tinggi berbahan baku tempe dan kembang kol dengan angka mean 9,04 dan setelah dilakukan perlakuan angka mean mencapai 9,16 dalam 1 bulan ada kenaikan mencapai 0,12 .
2. Sedangkan balita yang dijadikan kelompok kontrol dengan angka mean 9,81 dalam 1 bulan mencapai 9,87 ada kenaikan yaitu 0,06

3. Menunjukkan bahwa kelompok kontrol juga mengalami kenaikan beratbadantetapitidak sesignifikan kelompok eksperimen

\section{UCAPAN TERIMAKASIH}

Ucapan terima kasih kami sampaikan kepada :

1. Universitas Muhammadiyah Parepare yang telah memberikan dukungan dalam penelitian ini.

2. Kepala Dinas Kesehatan Kabupaten Enrekang

3. Kepala Puskesmas Kabere Kecamatan Cendana Kabupaten Enrekang

4. Semua pihak yang telah membantu dalam penyelesaian penelitian ini yang tidak dapat disebutkan satu per satu.

\section{DAFTAR PUSTAKA}

Ainun Mardhiah, R. R. (2020). Efektifitas Penyuluhan Dan Media Audio Visual Terhadap Pengetahuan Dan Sikap Ibu Anak Balita Gizi Kurang Di Puskesmas Medan Sunggal. Jurnal Kesehatan Global , 3, 18-25

Arsinah Habibah Fitriah, Y. K. (2017). Kreativitas Pengembangan Formula Tempe Generasi Dua. Jurnal Informasi Kesehatan Indonesia , 3, 96-103. 
Amazin. (2015). komposisi zat gizi dan 12 manfaat kesehatan kembang kol.

Kemenkes RI. (2014).Profil Kesehatan Indonesia Tahun 2013.From : https://pusdatin.kemkes.go.id/re sources/download/pusdatin/profi 1-kesehatan-indonesia/profilkesehatan-indonesia-2013.pdf

Kemenkes RI. (2018). Hasil Utama Riskesdas Tahun 2018. Badan Penelitian dan Pengembangan Kesehatan Kementrian Kesehatan Republik Indonesia. From:https://kesmas.kemkes.go. $\underline{\mathrm{id} / \text { assets/upload/dir_519d41d8c }}$ d98f00/files/Hasil-riskesdas$\underline{2018 \text { 1274.pdf }}$

Lilis Fauziah, N. R. (2017). Faktor Risiko Kejadian Gizi Kurang Pada Balita Usia 24-59 Bulan. Medika Tadulako, Jurnal Ilmiah Kedokteran , 4, 29-59.

Novriani. (2016). Pemanfaatan Daun Gamal Sebagai Pupuk Organik Cair (Poc) Untuk Meningkatkan. Klorofil Xi - 1 : 15 - 19, Juni 2016, 15-19.
Rovi'ati, A. E. (2019). Respon Kembang Kol Dataran Rendah Terhadap Kepekatan Nutrisi pada Floating Hydroponic System Termodifikasi. Agrosains 21(1): 11-15, 2019; pISSN: 1411-5786; eISSN: 2655 - 7339, 11-15.

Ruswindi,K.N. (2019). Pola Asuh Dan Status Gizi Balita. 110.DOI: $10.31227 /$ osf.io/vwda5

From

:https://www.researchgate.net/ publication/333826290_Pola_as uh_dan_status_gizi_balita

Sukini, M. 1. (2017). Efektivitas Konsumsi Nugget Tempe Kedelai Terhadap. Kenaikan berat badan balita gizi kurang. Jurnal

Kebidanan. 6(12):63DOI: 10.31 983/jkb.v6i12.1914

Puskesams Kabere (2020). Data Laporan Puskesmas kabere Tahun 2020. Enrekang:Puskesmas kabere 